\title{
骨移植とインプラント義歯による高度上頡歯槽堤萎縮症の治療
}

\author{
坪井陽一・横江 義彦・別所和久・陳 文熙 \\ 保圾 栄勇・宮川 淳・和田栄伸・村上賢一郎 \\ 飯塚忠彦
}

\section{Prosthodontic treatment for the extremely absorbed maxillae by using an implant prosthesis in conjunction with bone grafting}

\author{
Yoichi Tsuboi • Yoshihiko Yokoe • Kazuhisa Bessho Wen-Hsi Chen \\ Hideo Hosaka - Jun Mryagawa $\cdot$ Eishin Wada $\cdot$ Kenichiro Murakami \\ Tadahiko IIzukA
}

\begin{abstract}
Osseointegrated implants are currently recognized to be effective when used in preprosthetic surgery. Simultaneous bone grafting procedures to treat severely atrophic maxillae has, however, been little reported. Surgical procedures vary depending on the site and extent of bone resorption and bone quality; therefore, surgical planning should be carefully executed.

We have simultaneously placed osseointegrated implants in conjunction with bone grafting in 9 of 10 extremely absorbed maxillae. In this report, the clinical course of alveolar bone resorption around the fixtures, survival rate of the installed fixtures, and masticatory efficiency in relation to surgical procedure were discussed.

1. The patients consisted of nine females and one male, ranging in age from 16 to 58 years.

2. A total of 59 fixtures were placed. In totally edentulous cases, six to eight fixtures were placed. In partially edentulous cases, two to five fixtures were placed. Four fixtures failed to achieve osseouintegration. Mean overall survival rate was $93.2 \%$ for a 1.5 year followup period.

3. The degree of bone resorption was $0.6 \mathrm{~mm}$ in 6 months, and $1.0 \mathrm{~mm}$ in one year after initial surgery. After the first year, bone resorption rate is stabilized at $0.2 \mathrm{~mm}$ per year.

4. Regarding masticatory efficiency assessed pre- and post operatively, all of the cases showed extreme improvement. The mean masticatory score in totally edentulous cases was 32 points preoperative and 92.5 points postoperative; that in partial edentulous cases was 44 points preoperative and 97.5 postoperative.

These results indicate that osseointegrated implants in conjunction with bone grafting is a satisfactory procedure to restore masticatory function in patients with extreme atrophic maxillae.
\end{abstract}

Key words: osseointegrated implant (骨結合型インプラント), bone grafting (骨移植), reconstruction of the maxilla (上顎再建), interpositional bone graft (嵌入型骨移植)

京都大学医学部口腔外科学教室

（主任：飯塚忠彦教授）

Department of Oral and Maxillofacial Surgery,
Faculty of Medicine, Kyoto University (Chief:

Prof. Tadahiko Iizuka)

受付日: 平成 5 年 8 月 9 日 
緒

\section{言}

高度の骨萎縮を示す歯慒堤萎縮症に対しては, 従来よ り絶対的歯慒堤形成術が適用され，自家骨移植，人工骨 の填入，骨切り術等の方法が行われてきた。しかし，こ れらはいずれも可撤性義歯の維持安定の改善を目的とし たもので, 術後の咀嚼機能評価の成績においては, 固定 性の補綴物にはいたらなかった，近年，骨と一体化を示 す osseointegrated implant（骨結合型インプラント， Bränemark system) を用いた咬合再建例やその経年的 に優れた臨床成績が多施設より報告され，最近では骨移 植による顎骨再建部への応用も散見される.

京都大学医学部附属病院歯科口腔外科では平成元年 2 月以来, 補経困難症例を対象として本システムの臨床応 用を行っている．今回はこれら症例のうち，骨移植によ る絶対的歯槽堤形成術にインプラント治療を組み合わせ た上顎10例について，症例の概要を報告するとともに， インプラントの定着率, インプラント体周囲の歯槽骨吸 収の程度, 術前後の咀嚼機能の変化について検討を行っ たので報告する。

\section{対象および方法}

\section{1. 研究対象}

京都大学医学部附属病院歯科口腔外科に括いて平成元 年 2 月より平成 5 年 3 月までの 4 年 1 か月間に骨移植を 併用した骨結合型インプラントによる咬合再建を行った 上顎症例は，女性 9 例，男性 1 例の計 10 例で，施術時年 齢は18歳から58歳であった。これらの患者の主訴は義歯 の維持不良 7 例，義歯装着不能の 3 例であった，久損状 況では全部欠損 6 例，局部欠損 4 例であった，顎骨萎縮 をきたしたと思われる原因としては外傷 5 例，ら蝕 2 例，歯周疾患 3 例であった（表 1 ）。これらのいずれの 症例においても従来の可撤性義歯による咀嚼機能および 審美性の改善は困難であり，インプラントによる治療を 検討した。 しかしこれらすべての症例に拈いてインプラ ント埋入に必要な歯槽骨の高径, 幅径の高度な喪失が認 められた。 そこでインプラント埋入母地として骨移植が 不可欠であると診断された。

\section{2. 研究方法}

1) 埋入されたインプラント周囲の歯槽骨の吸収度の 判定はインプラント植立より 6 か月，12か月，18か月， 2 年経過時点での歯科用X線検査により行った。計測法 はフィクスチャーの近心部と遠心部で上縁からの距離を 測定し両者の平均值を求めた. フィクスチャーのネジ山 の 1 ピッチが $0.6 \mathrm{~mm}$ であることを利用して距離測定の 尺度とした（図1）.

2）インプラントの定着率については 2 次手術時に次
表 1 対象症例

\begin{tabular}{c|c|c|c|c}
\hline 症例 & $\begin{array}{c}\text { 年齢 } \\
\text { (歳) }\end{array}$ & 性別 & 部位欠損 & 欠損の原因 \\
\hline 1 & 40 & 女 & $\underline{7+7}$ & 歯周病 \\
2 & 54 & 女 & $\underline{7+7}$ & 5 蝕 \\
3 & 18 & 女 & $\underline{2+2}$ & 交通事故 \\
4 & 30 & 男 & $\underline{7+7}$ & スキー事故 \\
5 & 58 & 女 & $\underline{7+7}$ & 歯周病 \\
6 & 21 & 女 & $\underline{2+1}$ & 交通事故 \\
7 & 19 & 女 & $\underline{5+4}$ & 交通事故 \\
8 & 53 & 女 & $\underline{7+7}$ & 万 蝕 \\
9 & 51 & 女 & $\underline{7+7}$ & 齿周病 \\
10 & 16 & 女 & $\underline{1+4}$ & 交通事故 \\
\hline
\end{tabular}

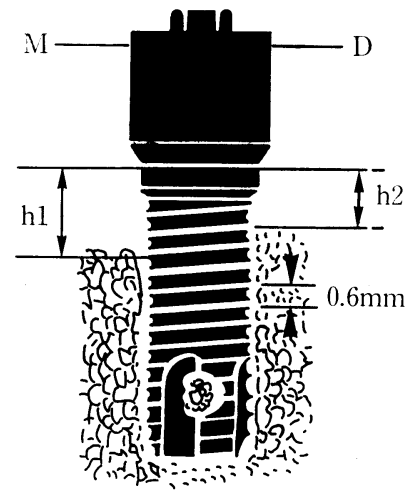

図 1 骨吸収量の計測法 $\underset{(\mathrm{mm})}{\text { 吸収量 }}=\frac{\mathrm{h}_{1}+\mathrm{h}_{2}}{2}$

のよらな基準により判定した。

(1) 2 次手術時のアバットメント接合時にフィクスチ ャーの動摇, 回転がない.

(2) トルクドライバーによってアバットメントを 20 $\mathrm{Ncm}$ で締め付けた時にフィクスチャーの回転がなく， 患者が疼痛を自覚しない。

（3）咀嚼能力の調査は佐藤ら ${ }^{1)}$ の咀嚼機能評価表を用 いて，術前後にアンケート調査を行った。食品それぞれ に 5 点を与えその合計で咀嚼能力を評価した（表 2 ）.

術 式

\section{1. 術前処置}

術前処置として，徹底した口腔衛生指導と残存歯のう 蝕処置, 根管治療, 歯周治療を先行させた。不正な咬 合を持つ症例ではフィクスチャー埋入前に咬合改善を行 


\section{表 2 咀嚼機能評価表}

アンケートにより, 表中の食品で食べられる物 に 5 点のスコアを与光, 合計点を個人の咀嚼機 能とした.

\begin{tabular}{|c|c|}
\hline グループ & 食 品 名 \\
\hline 1 & $\begin{array}{l}\text { 豆鹤, ごはん } \\
5 \text { どん, プリン }\end{array}$ \\
\hline 2 & $\begin{array}{l}\text { レタス, エビ天ぷら } \\
\text { きゅ5り，焼きるち }\end{array}$ \\
\hline 3 & $\begin{array}{l}\text { ビフテキ，たくまん } \\
\text { 酢だこ，堅いビスケット }\end{array}$ \\
\hline 4 & $\begin{array}{l}\text { 括こし, 堅いせんべい } \\
\text { とり貝，古いたくあん }\end{array}$ \\
\hline 5 & $\begin{array}{l}\text { するめ, ガム } \\
\text { りんご丸かじり，もめん系を切る }\end{array}$ \\
\hline
\end{tabular}

い, 暫間修復物の作成を行った. 多数歯欠損では治療用 義歯の作成を行い，粘膜調整，咬合高径の改善を終了さ せた。 また全症例で, 最終補綴物における適切なインプ ラントのアクセスホールの設定と埋入角度を決定するた めにサージカルステントを作成した，症例によっては旧 義歯を複製して，インプラント埋入予定部位をくり抜い てサージカルステントとした。 また部分歯欠損において は残存歯固定型のサージカルステントを作成した（写真 1). 症例によっては, インプラント埋入予定位置の歯 槽形態の精査を行うために, 一定の大きさの金属球, 金 属棒, ガッタパーチャなどのX線不透過性マーカーをサ ージカルステントに装着して頭部X線規格撮影, パノラ マ撮影を行った。

\section{2. 手術術式}

当科で使用した osseointegrated implant は, 3 つの 部分に大別される. それは顎骨内に埋入されるチタン製 のネジ状をしたフィクスチャー, 粘膜軟組織を貫通して 外部と連結するアバットメント, 上部補綴物に鋳接され るゴールドシリンダーよりなる.

手術はフィクスチャーを顎骨に埋入する 1 次手術, ア ベットメントをフィクスチャーに接合する 2 次手術に分 けられる. 1 次手術は 1 例のみ局所麻酔下で行ったが, 残り 9 例は全身麻醉下にて行った。骨移植手術は原則と しては, 患者の負担を軽減するため, 10 例中 9 例は 1 次 手術之同時に行い, 1 例のみ移植骨の生着を待らフィク スチャーを埋入した。移植術式は onlay graft 3 例, inlay graft 4 例, また骨切りを行い, 骨を嵌入する嵌 入型骨移植 (interpositional graft) を 3 例に行った. 使 用した移植骨は自家腸骨 3 例, 下顎オトガイ部骨 3 例, 人工骨 1 例であった。 1 次手術後 4 週間は義歯の装着を

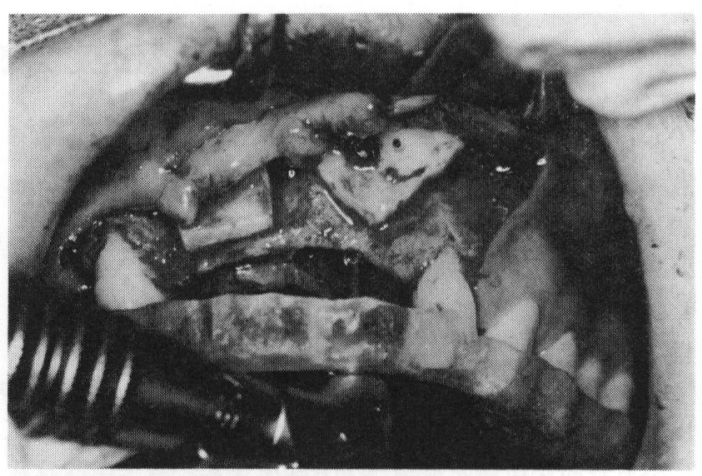

写真 1 診断用模型上で最終補綴物をワックスアッ プし残存歯固定型のサージカルステントの 作成を行い, 手術時に口腔内に装着し, 正 確なフィクスチャ一埋人位置を決定する。

禁じ，その後に旧義歯の裏面を軟性材料によりリベース して装着させた. 移植骨および埋入したフィクスチャー に直接咀嚼力が集中しないように定期的に来院させ, 厳 重な観察を行った。 1 次手術と 2 次手術の間隔は, 移植 骨の生着とフィクスチャーと骨との結合を得るために 6 か月以上の治癒期間を拈いた（表 3 ). 治癒期間は 1 次 手術時の骨質の評価, フィクスチャーの初期固定の程 度, 移植骨の状態, 被覆する粘膜骨膜の質によって適宜 延長したが， 2 次手術までの期間が 1 年を越えないよう に配慮した。 また必要とされた粘膜に詨する処置として 2 次手術時に上唇小带切除 1 例, 粘膜移植による口腔前 庭形成術をそれぞれ 1 例に打いて行った。

\section{3. 補緅術式}

2 次手術後の軟組織の治㾓を待ら， 2 週目より上部構 造の作成を開始した。 この基本術式は（1）予備印象, （2）個人トレーの作成，（3）本印象，（4）咬合採得,

（5）人工歯配列試適，（6）金属フレームワーク試適,

（7）上部構造の装着の順であった.

\section{症例}

代表的な症例 3 例について記載する.

症例 1 : 30歳 男性.

平成 3 年 4 月, 上下顎の咬合高径の低下による, 顔貌 のアンバランス报よび義歯の不安定を主訴に来院した (写真 2 ). 咀嚼機能スコアーは30であった. 術前のX線 検査では, 上顎は水平性の高度な吸収を示し, 臼歯部で は上顎洞底と歯槽頂とは極度に近接していた（写真了）。

診 断: 上顎歯槽骨萎縮症, 上顎全歯欠損.

処置および経過：平成 3 年11月にまず自家腸骨を必要 量採取し，ついで Le Fort I 型骨切り術を行い, 歯槽 骨を上顎骨体より分離し，採取した腸骨を遊離骨体部に フィクスチャーにより維持固定したのち, 移植腸骨と歯 
表 3 治療成績表（1）

\begin{tabular}{|c|c|c|c|c|c|c|}
\hline \multirow{2}{*}{ 症例 } & \multirow{2}{*}{ 植立部位 } & \multirow{2}{*}{$\begin{array}{c}フ_{1} \text { クスチャー } \\
(\mathrm{mm}) \times \text { 長さ数 }\end{array}$} & \multicolumn{2}{|c|}{ 移 植 骨 } & \multirow{2}{*}{ 移植術式 } & \multirow{2}{*}{$\begin{array}{l}2 \text { 次手術までの } \\
\text { 期間(か月) }\end{array}$} \\
\hline & & & 種 類 & 時 期 & & \\
\hline 1 & $7+7$ & $\begin{array}{l}20 \times 2 \\
15 \times 4\end{array}$ & 晹 骨 & 1 次手術時 & Onlay graft & 6 \\
\hline 2 & $7 \uparrow 7$ & $\begin{array}{l}10 \times 1 \\
13 \times 2 \\
15 \times 3 \\
18 \times 1\end{array}$ & 腸骨 & 1 次手術時 & Onlay graft & 11 \\
\hline 3 & $2+2$ & $20 \times 4$ & $\begin{array}{l}\text { 下顎 } \\
\text { オトガイ骨 }\end{array}$ & 1 次手術時 & Inlay graft & 6 \\
\hline 4 & $7+7$ & $\begin{array}{l}10 \times 1 \\
15 \times 3 \\
18 \times 3 \\
20 \times 1\end{array}$ & 腸骨 & 1 次手術時 & $\begin{array}{l}\text { Le Fort I+osteotomy+ } \\
\text { Interpositional graft }\end{array}$ & 8 \\
\hline 5 & $7+7$ & $\begin{array}{l}10 \times 1 \\
13 \times 1 \\
15 \times 3 \\
18 \times 1 \\
20 \times 1\end{array}$ & 腸骨 & 1 次手術時 & $\begin{array}{l}\text { Onlay graft }+ \\
\text { Sinus Lift }\end{array}$ & 8 \\
\hline 6 & $2+1$ & $18 \times 3$ & $\begin{array}{l}\text { 下顎 } \\
\text { オトガイ骨 }\end{array}$ & 1 次手術時 & Inlay graft & 8 \\
\hline 7 & $\underline{5+4}$ & $\begin{array}{l}16 \times 4 \\
18 \times 1\end{array}$ & 人工骨 & 1 次手術時 & Inlay graft & 8 \\
\hline 8 & $7+7$ & $18 \times 8$ & 腸骨 & 1 次手術前 6 か月 & Inlay graft & 8 \\
\hline 9 & $7 \sim 7$ & $\begin{array}{l}18 \times 3 \\
20 \times 2 \\
15 \times 3\end{array}$ & 腸骨 & 1 次手術時 & $\begin{array}{l}\text { Le Fort I osteotomy }+ \\
\text { Interpositional graft }\end{array}$ & 8 \\
\hline 10 & $1+4$ & $\begin{array}{l}15 \times 1 \\
18 \times 2\end{array}$ & $\begin{array}{l}\text { 下顎 } \\
\text { オドイ骨 }\end{array}$ & 1 次手術時 & $\begin{array}{l}\text { Segmental osteotomy }+ \\
\text { Interpositional graft }\end{array}$ & 8 \\
\hline
\end{tabular}

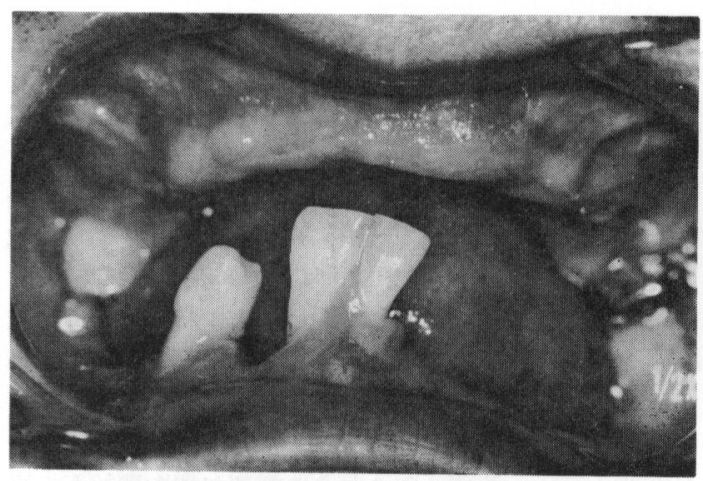

写真 2 初診時口腔内

上顎の顎堤は高度の萎縮を示した。

槽骨を一塊としてミニプレートにより上顎骨に固定した （写真 4 ）。な㘯腸採取部には腸骨稜部の術後の陥凹を 防止するためにヒドロキシアパタイト製の腸骨スペーサ

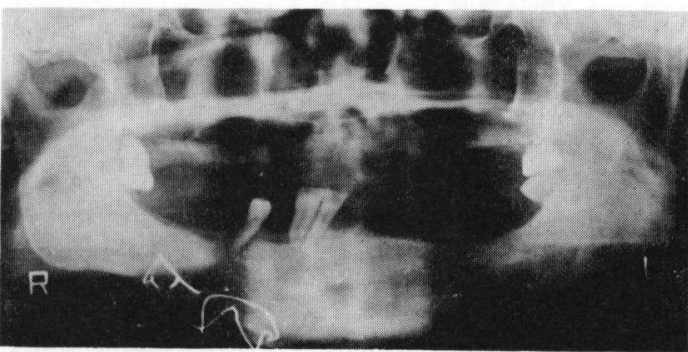

写真 3 初診時 $\mathrm{X}$ 線写真 上顎洞底と歯槽頂は極度に近接。

一を填入した. フィクスチャーの長さは $13 \mathrm{~mm} 1$ 本, $15 \mathrm{~mm} 3$ 本, $18 \mathrm{~mm} 3$ 本, $20 \mathrm{~mm} 1$ 本の計 8 本であ った。 な括下顎は局所麻酔下にて上顎の 1 次手術の 3 か 月前にフィクスチャー埋入を行った.

1 次手術より 8 か月目の平成 4 年 7 月, 2 次手術を行 


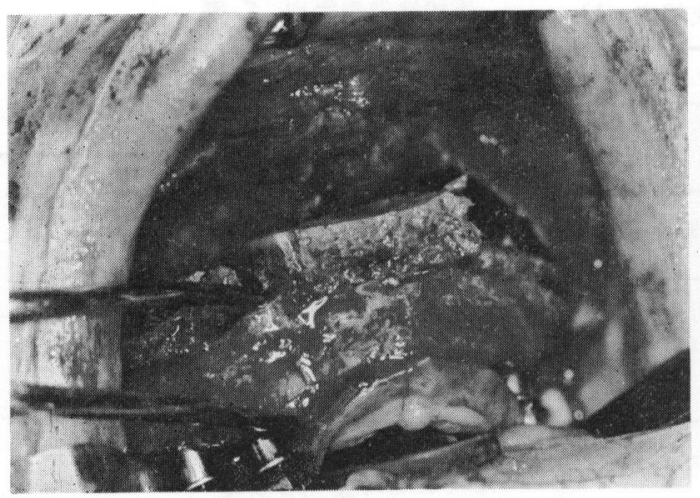

a . Le Fort I 型骨切り術を行い, 腸骨を遊離した 㐘槽部にフィクスチャーで維持固定.

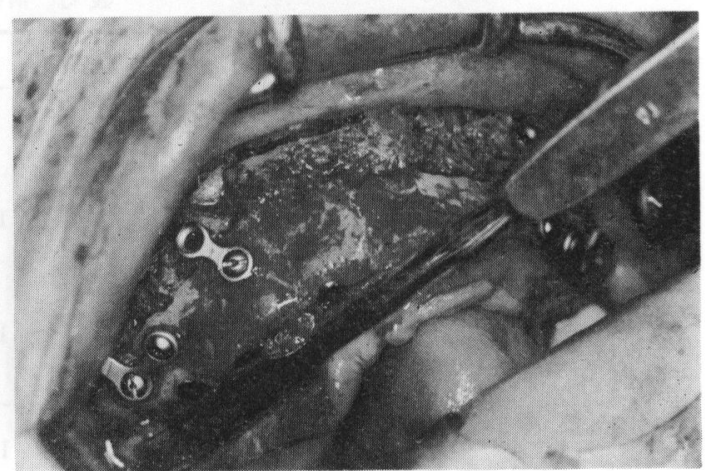

b. 一体となった移植腸骨と歯槽骨をチタン製のミ ニプレートで上顎骨に固定.

写真 4

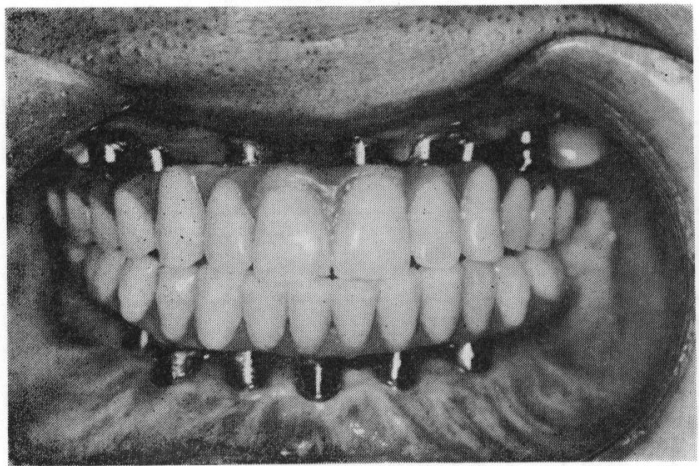

a 、固定性のインプラント義歯を装着。

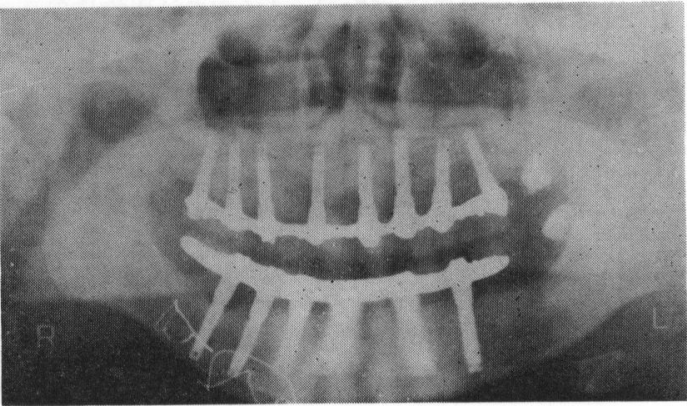

b.インプラント義歯装着時の X線写真.

写真 5

い,トルクコントローラーにより $20 \mathrm{~N} \mathrm{~cm}$ でアバット メントを接続し，この際すべてのフィクスチャーの定着 を確認しえた。接続したアバットメントは $4.0 \mathrm{~mm} 5$ 本, $5.5 \mathrm{~mm} 2$ 本, $3 \mathrm{~mm} 1$ 本であった. な扣下顎も同 時に 2 次手術を行った.

平成 4 年 8 月より上下顎の補綴処置を開始し, 平成 4 年 9 月にブリッジを装着した（写真 5 )。上顎の 8 本の インプラント周囲の平均の骨吸収度は, 埋入後 6 か月で $0.5 \mathrm{~mm}, 12$ か月で $1.0 \mathrm{~mm}, 18$ か月 $1.0 \mathrm{~mm}$ と安定し た数值を示した. ブリッジ装着後, 顔貌のバランスも改 善され, 約 4 週で咀獣機能は, 術前のスコアー 30 から 100 へと著明な改善が得られた。

症例 $2: 16$ 歳 女性.

平成 3 年 3 月初診。 1234 部の歯槽骨の欠損が大き く, 可撤性義歯は不安定で, 咀嚼機能スコアーは40であ った，有床義歯に対する強い拒否感を持って扣り，術前 のX線検査では歯槽骨の欠損は $\mid 23$ 部に执いて著明で,
インプラント体の維持安定には同部の骨の増量が必要と 判断した（写真 6 ).

診 断： $1 \uparrow 4$ 欠損, 外傷による|1234 部歯槽骨欠 損.

処置および経過：平成 3 年 7 月, 全身麻酔下に $\mid 1234$ 部に前方歯槽骨切り術を行い, 下顎オトガイ部より採取 した骨を填入させ，歯槽堤の垂直的煩舌的な形態改善を 行うのと同時にフィクスチャーの埋入を行い移植骨を維 持固定した.フィクスチャーの長さは $15 \mathrm{~mm} 1$ 本, 18 $\mathrm{mm} 2$ 本であった（写真 7 ）.

1 次手術より 8 か月の平成 4 年 3 月, 局所麻酔下に 2 次手術を行い, 平成 4 年 3 月より補綴処置を開始し, 平 成 4 年 4 月にブリッジを装着した（写真 8 ）。3 本のイ ンプラント周囲の骨吸収は埋入後 6 か月で $0 \mathrm{~mm}, 12$ か 月で $0.6 \mathrm{~mm}, 18$ か月で $0.6 \mathrm{~mm}$ と安定した数值を示 した. ブリッジ装着後, 審美的にも満足のいく結果が得 られ, 約 4 週で咀嚼機能は, 術前のスコアー40から95 


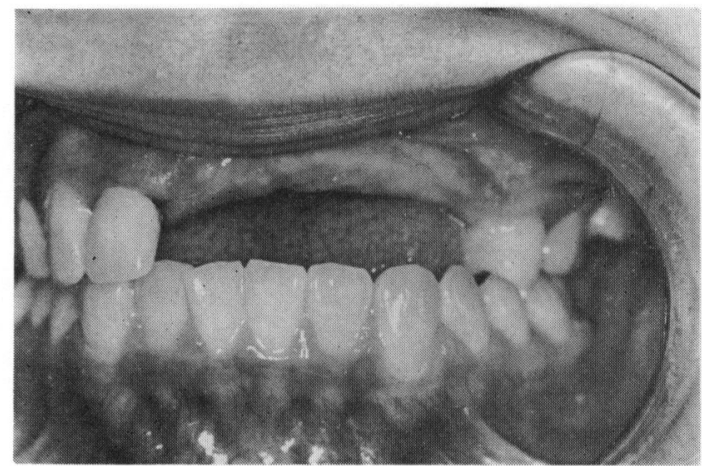

写真 6 初診時口腔内

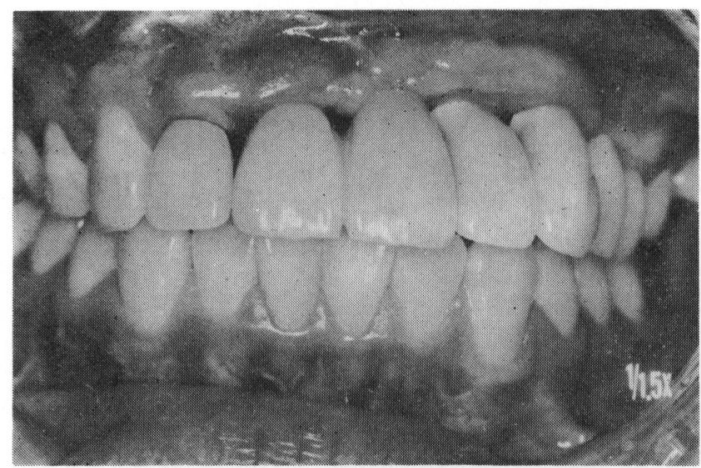

a . 固定性のインプラント義画を装着.

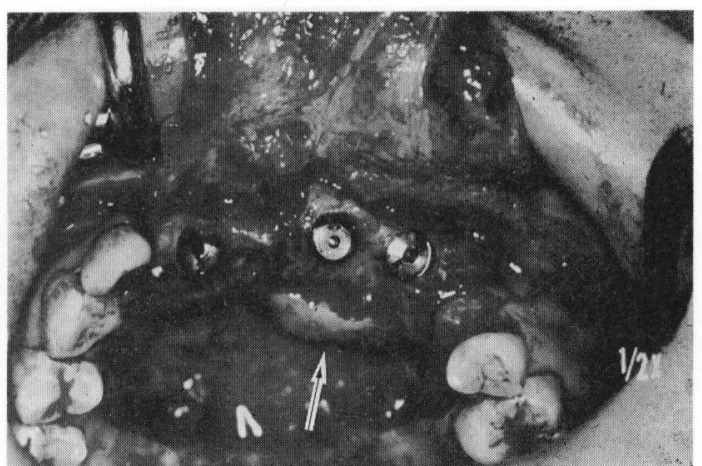

写真 7 前方迷槽骨切り術を行い, オトガイ部より 採取した骨の媜入（矢印）により歯槽堤の 形態改善と同時にフィクスチャーを埋入.

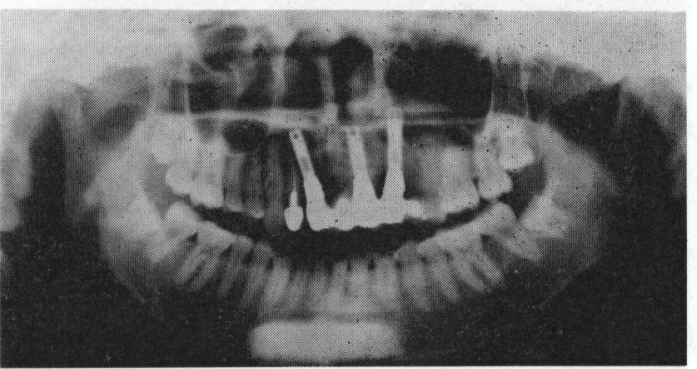

b. インプラント義歯装着時の X線写真.

写真 8

著明な改善が得られた。

症例 3:40歳 女性.

上下顎の歯の動摇が著明で, 近歯科医院において抜歯 後, 可撤性の義歯を装着するも, 食事や日常会話にも不 自由を感じるために来院した。

診 断 : 上顎全歯欠損, 上顎歯槽骨萎縮症.

処置および経過: 平成 3 年 2 月全身麻酔下にて, 縦 $2.5 \mathrm{~cm}$, 横 $4.0 \mathrm{~cm}$ の馬蹄形の腸骨を onlay graft し, フィクスチャー 6 本で上顎骨に固定した。フィクスチャ 一の長さは $15 \mathrm{~mm} 4$ 本, $20 \mathrm{~mm} \mathrm{2}$ 本であった（写真 9)。な拈下頡欠損部にも同時に 4 本のフィクスチャー を埋入した。

平成 3 年 9 月, 局所麻酔下に 2 次手術を行い, 平成 4 年10月より補綴処置を開始し, 平成 4 年 12 月にバーとク リップにより固定するオバーレイデンチャーを装着した （写真10）。な排同時に下顎の補綴を行った。 上顎の 6 本 のインプラント周囲の骨吸収は埋入後 6 か月で $0 \mathrm{~mm}$, 12 か月で $0 \mathrm{~mm}, 18$ 月で $0.5 \mathrm{~mm}, 24$ か月で $0.5 \mathrm{~mm}$
と安定した数值を示した、インプラントを維持源とした 可撤性義歯は審美的にも満足のいく結果が得られ，約 4 週で咀嚼機能は, 術前のスコアー40から 85 と著明な改善 が得られた。

結果

骨移植と併せて上顎骨に埋入されたフィクスチャーの 埋入総数は 59 本であった. 無歯顎症例では 8 本埋入 3 例, 7 本埋入 2 例, 6 本埋入 1 例, 計 44 本, 平均 7.3 本 であった. 部分欠損症例では 4 本埋入 2 例, 3 本埋入 1 例, 2 本埋入 1 例の計 12 本, 平均 3 本であった。 骨移植 を伴う上顎症例でフィクスチャー埋入を行った 1 次手術 より 2 次手術までの期間は $6 \sim 11 か$ 月, 平均 7.9 か月で あった（表了）.

フィクスチャーの定着率は, 2 次手術時と最終術後経 過日数で判定した. 2 次手術時に 59 本中， 2 本（1 症 例）の定着が得られず，2次手術時に括ける定着率は 


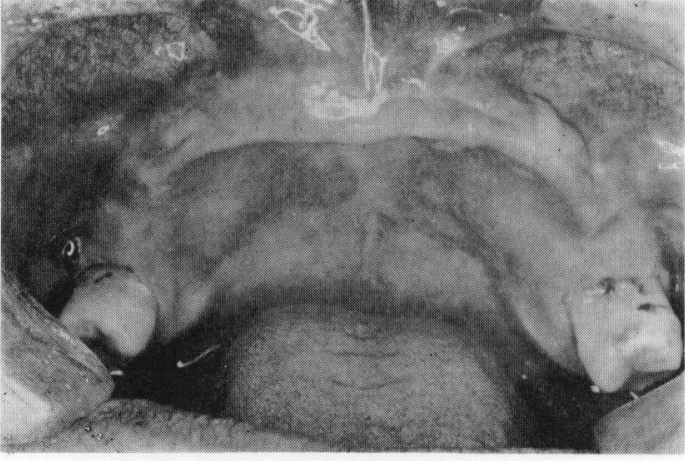

a. 術前口腔内

高度の上顎歯槽堤萎縮を示し, 可撤性義歯の維持 安定は不良であった。

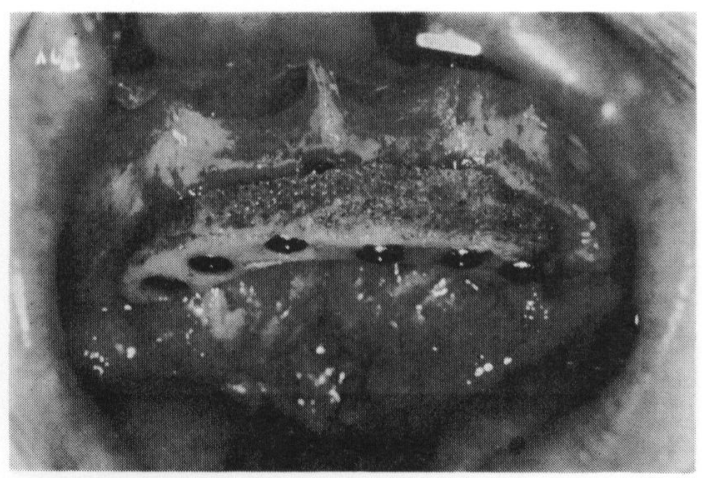

b ．馬蹄形に調整した腸骨を萎縮した上顎歯槽部に onlay graft, 移植骨は 6 本のフィクスチャーに より固定.

写真 9

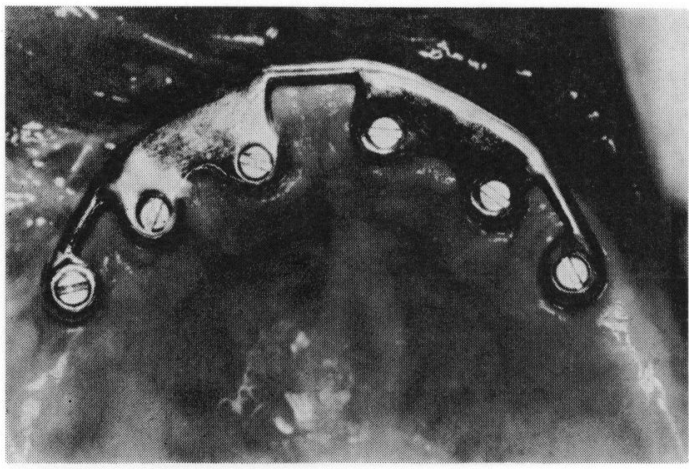

a 、インプラント体にインプラント義茵をバーとク リップで維持する構造体を固定.

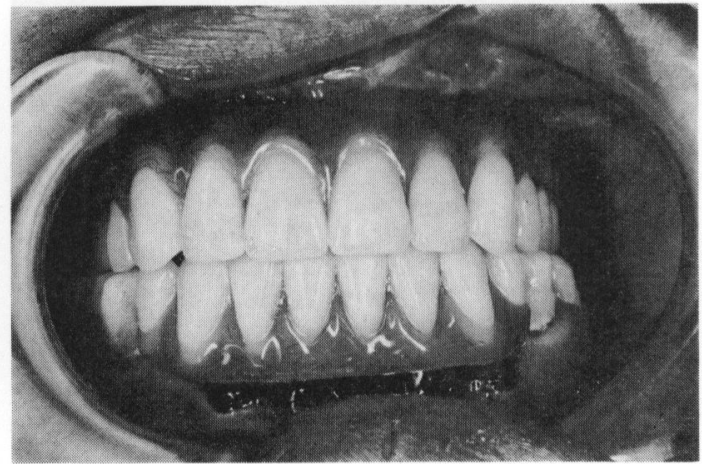

b. バーで強固に維持されるインプラント義菌を装 着.

写真 10

96. $6 \%$ となった。 また他の 1 症例に特いては補綴物装着 後 1 年でフィクスチャーの動摇はないものの咬合痛を認 めたため, アバットメントを除去し, 骨との再度の固定 を期待して 2 本を埋入状態にした。このため術後経過日 数 1 年 6 か月時点でのフィクスチャーの定着率は平均で 93. $2 \%$ となった（表 4 ）.

補綴物装着後の咀嚼能力の調査は, 佐藤らの咀嚼機能 評価表を用いた。無歯顎症例では術前の平均スコアー32 が補綴物装着後では92.5 と改善を示した。部分歯欠損症 例では術前の平均スコアー44が補綴物装着後には97.5 著明な改善を示した. 全症例に和ける咀嚼能力の変化は 平均 38 より95であり，著しい改善を認めた（表 5 ）。

インプラント周囲の歯槽骨の吸収は, 植立より 6 か月 以内に $0.6 \sim 1.0 \mathrm{~mm}$ の比較的急な骨吸収を示したが, 術後 1 年以降ではその程度は穏やかになり onlay graft の 1 例を除いては, その吸収はその後の 6 か月で平均
$0.1 \mathrm{~mm}$ 以下とほぼ同程度の值を示した（図 2）。また 埋入位置による骨吸収の程度には差を認めなかった。

考察

口腔領域の骨欠損を伴う骨折や腫瘍切除後の顎骨再建 には, 従来より自家骨や人工骨の移植および填塞等が行 われている。しかしこれらは形態再建に終始することが 多く，審美性执よび機能性を含めた咬合の再構成を得る ことは困難であった。近年, 外傷や腫瘍切除に伴う歯お よび骨の欠損, さらに高度の骨吸収を伴ら歯槽堤萎縮症 に対して Brånemark らにより開発された osseointegrated implant の臨床応用が報告されるようになった ${ }^{2,3)}$.

Brånemark システムは一歯欠損から無歯顎までの広 い症例に適用され，通常の歯の欠損については長期間 にわたる高い成功率と安全性が臨床的に確認されてい 
表 4 治療成績表 (2)

フィクスチャ一の埋入数拈よび定着率

\begin{tabular}{|c|c|c|c|}
\hline 症例 & $\begin{array}{l}\text { フィクスチャー } \\
\text { (定着数/埋入数） }\end{array}$ & 定着率(\%) & $\begin{array}{l}\text { 術後経過 } \\
\text { 日 数 }\end{array}$ \\
\hline 1 & $6 / 6$ & 100 & 1 年11か月 \\
\hline 2 & $7 / 7$ & 100 & 2 年 4 加 \\
\hline 3 & $4 / 4$ & 100 & 1 年 1 か月 \\
\hline 4 & $8 / 8$ & 100 & 1 年 8 力月 \\
\hline 5 & $5 / 7$ & 71.4 & 1 年 7 か月 \\
\hline 6 & $3 / 3$ & 100 & 1 年 \\
\hline 7 & $5 / 5$ & 100 & 1 年 \\
\hline 8 & $8 / 8$ & 100 & 6 か月 \\
\hline 9 & $8 / 8\left(6 / 8^{*}\right)$ & $100\left(75^{*}\right)$ & 1 年10か月 \\
\hline 10 & $3 / 3$ & 100 & 1 年11か月 \\
\hline 平均 & & $96.6(93.2)$ & 1 年 6 か月 \\
\hline
\end{tabular}

表 5 治療成䋶表 (3)

術前術後の㕨嚼の能力の変化

\begin{tabular}{|c|c|c|c|}
\hline \multirow[b]{2}{*}{ 症例 } & \multirow[b]{2}{*}{ 歯牙久損状態 } & \multicolumn{2}{|c|}{ 叫嚼能力 } \\
\hline & & $\begin{array}{l}\text { 術前 }(\%) \\
\text { (可撤性義檤) }\end{array}$ & $\begin{array}{l}\text { 術後（\%) } \\
(\text { インプラント義幽） }\end{array}$ \\
\hline 1 & $7+7$ & 20 & 85 \\
\hline 2 & $7+7$ & 30 & 95 \\
\hline 3 & $2+2$ & 70 & 95 \\
\hline 4 & $7+7$ & 30 & 100 \\
\hline 5 & $7+7$ & 30 & 75 \\
\hline 6 & $2 \uparrow 1$ & 60 & 100 \\
\hline 7 & $5+4$ & 30 & 100 \\
\hline 8 & $7+7$ & 30 & 100 \\
\hline 9 & $7+7$ & 20 & 100 \\
\hline 10 & $1+4$ & 60 & 95 \\
\hline
\end{tabular}

る ${ }^{4 \sim 7)}$. すでに下顎では，顎骨再建に伴うインプラント 応用についても, 骨移植を先行し, 骨の生着後にフィク スチャーの植立を行った報告は比較的多〈2,8), 本シス テムは顎骨再建外科に打いても有用性が高い。しかし上 顎では, 移植骨の良好な維持固定と頻回の手術を避ける ためには骨移植手術と同時にフィクスチャーを埋入する ことが望まれる。近年, 欧米を中心として高度の骨吸収 を示す上顎骨萎縮に対してインプラントと骨移植を組み

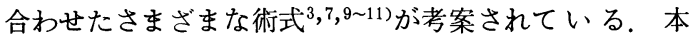
邦においてもこらした術式の概略に関する学会報告は散 見されるが，適応に関する考察にはいたってはいない. onlay graft による再建術式は，手術操作が比較的容易 であるにもかかわらず，上顎の極度の骨吸収を示す症

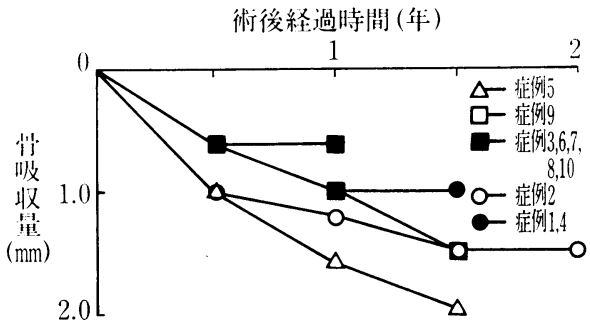

図 2 インプラント治療後の茵槽骨吸収の経時的 変化

例，上顎洞が大きく発達した症例，また上下顎の顎間関 係の改善を必要とする症例などへの適応は困難である. 骨移植と同時の人工歯根の埋入に関する報告は散見され るが3,9 11)，これは人工歯根といら異物の存在下におけ る移植骨の生着, 長期的な安定とい5 2 つの相反する問 題点を有している。 こうした問題点を補う目的で，われ われは症例によっては骨切り術を行い移植骨を挾み込む 嵌入型骨移植 (interpositional bone graft) を行った.

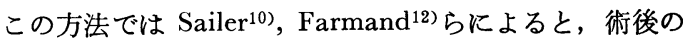
骨吸収が onlay graft に比較して小さく，しかも高さ拉 よび矢状面に和ける改善の自由度が高いとしている，さ らに多くは骨移植とインプラント埋入を同時に行うこと ができ，患者の苦痛の機会を減じることができるが，一 方で手術侵襲の大きいことが欠点である.

骨移植に伴ら周囲の軟組織の取り扱いに関しても，細 心の注意が必要である，とくに骨膜剝離は慎重さを要求 され，フラビーガムが存在すればこれを利用し伸展させ て, 緊張なく縫合を行い, 術後の創の哆開が生じないよ らにマットレス縫合を行う．インプラント周囲に角化性 歯肉を欠く場合は粘膜移植が，口唇粘膜の緊張が強く歯 慒堤萎縮を示す場合には小帯切除形成術や口腔前庭形成 術などが必要とされる。

術式の改善に加えて，一過性の虚血防止と治癒促進の 目的で高圧酸素療法の併用も行われている ${ }^{13)}$.

移植骨の採取部位については，腸骨は十分量の骨が採 取可能であるが，手術侵襲が大きく，術野も2 分され る.これに対して下顎オトガイ部よりの骨採取は，以前

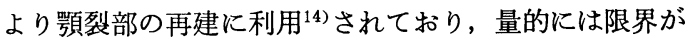
あるものの, 同一の術野で, しかも手術侵襲が比較的小 さいといら利点がある ${ }^{15)}$.

1 次手術より 2 次手術までの期間については現在明確 な基準はないが，われわれの施設では治瘉期間を 8 か月 間を標準としており，インプラント周囲の歯槽骨吸収の 程度も術後 1 年で $0.6 \sim 1.0 \mathrm{~mm}$ と良好な結果を得てい る. Brånemark ${ }^{16)}$, Lekholm ${ }^{17)}$ らによると，骨移植と同 時のフィクスチャー埋入手術では 1 次手術後12か月以上 放置するとフィクスチャー周囲の骨吸収が過度に進行す 
る症例が多く, $8 \sim 9$ か月後に 2 次手術を行い, 正しく 機能する補綴物を装着させることにより過度の骨吸収は 抑制できるとしている16,17,18). しかし骨移植なしの上顎 無歯顎インプラント治療に比較すると骨移植と同時のフ ィクスチャー埋入例の予後は格段に不良であるとの報 告 ${ }^{11,19)}$ もあり, 適応症と術式の正しい選択が重要と思わ れる。

Osseointegrated implant の 10 年経過後の定着率は上 顎では $81 \%$ と報告4) されているが，われわれの症例の経 過観察期間中（平均 1 年 6 か月）に护けるフィクスチャ 一定着率は，93.2\% と比較的良好であった。 しかし症例 5 に拈いて上顎臼歯部に埋入されたフィクスチャーは 2 次手術時に定着が得られていなかった，移植骨の安定と フ、ィクスチャーの初期固定の得にくい部位への埋入は, 慎重に行らとともに，下顎に比して上顎での経年的な非 定着率の高さを考慮して, 必要本数以上のフィクスチャ 一を埋入しておくことも重要と考えられる.

補綴物装着後の咀嚼能力の調査によって無歯顎症例で は, 術前の平均スコアー32が補経物装着後では92.5, 部 分歯欠損症例では術前 44 が術後 97.5 と著明な改善を示し た. これらの数值は, 下顎無歯顎症例に対する固定性ブ リッジの咀嚼能力の変化を調查した上田ら ${ }^{20)}$ の報告とほ ぼ同様の結果を示した。

上䅡に骨移植を併用した osseointegrated implant の 応用は咀嚼能力の改善, 義歯の安定性, 違和感の少な さ，審美性などの点において下顎無歯顎症例と同様に優 れた臨床結果を得ることができた。しかし手術侵襲が通 常のインプラント義歯の治療と比較して大きくなること る欠点といえる。適応症と術式の選択を慎重に行い，よ り少ない手術侵襲で高い成功率を得る種々の改善と工夫 が重要と思われる．今後症例を重ねるとともに的確な症 例の選択基準を検討したい.

\section{結語}

京都大学医学部附属病院歯科口腔外科に和ける, 10例 の高度上顓歯槽堤萎縮症の患者に骨移植と osseointegrated implant を用いた咬合再建を行い, 咀緭能力の変 化，インプラント周囲の歯槽骨の吸収度, さらにインプ ラントの定着率について検討した.

1. 補経物装着後の咀嚼能力については, 無歯顎症例 では術前の平均スコアー32が補緅物装着後では 92.5 , 部 分歯欠損症例では術前 44 が術後 97.5 と著明な改善を示し た.

2. インプラント 周囲の歯槽骨の吸収は，植立より 6 か月以内に 0.6〜 $1.0 \mathrm{~mm}$ の急激な骨吸収を示したが, 術後 1 年以降ではその程度は穏やかになり, その吸収は 平均 $0.2 \mathrm{~mm}$ 以下とほぼ取じ值を示した。

3. フィクスチャーの定着率は 2 次手術時と最終術後
経過日数で判定した. 2 次手術時に59本中, 1 例におい て 2 本の定着が得られなかった。 フィクスチャーの定着 率は 2 次手術時で $96.6 \%$, 術後 1 年 6 か月で93. $2 \%$ あっ た.

以上より高度上顎歯槽堤萎縮症の治療に骨移植を伴う osseointegrated implant を用いた咬合再建法は咀嚼機 能の改善に優れ, フィクスチャーの定着率においては 1 年 6 か月と短期間の観察ではあるが良好なことが判明し た.

本論文の要旨は, 第46回日本口腔科学会総会 (名古 屋, 平成 4 年 4 月 17 日）にて発表した。

\section{引用文 献}

1）佐藤裕二, 石田英作, 他 : 総義歯装着の食品摂 取状況。補綴誌 32：774-779 1988.

2) Dodson, T.B. and Smith, R.A.: Mandibular reconstruction with autogenous and alloplastic materials following resection of an odontogenic myxoma. Int $\mathrm{J}$ Oral Maxillofac Implants 2: 105-107 1987.

3) Kellor, E.E. and Roekel, N.B.V.: Prostheticsurgical reconstruction of the severely resorved maxilla with iliac bone grafting and tissue-integrated prostheses: Int $\mathrm{J}$ Oral Maxillofac Implants 2: 155-165 1987.

4) Adell, R., Lekholm, U., et al.: A 15-year study of osseointegrated implants in the treatment of the edentulous jaw. Int $\mathrm{J}$ Oral Maxillofac Surg 10: 387-416 1981.

5) Adell, R.: Tissue-Integrated Prostheses. Quintessence Publ Co, Chicago, 1987, p 175186.

6) Adell, R., Eriksson, B., et al.: long-term follow-up study of osseointegrated implants in the treatment of totally edentulous jaws. Int J Oral Maxillofac Implants 5: 347-359 1990.

7) Breine, U. and Brånemark, P-I : Reconstruction of alveolar jaw bone. Scand J Plast Reconstr Surg 14: 23-48 1980.

8) Keller, E.E., Desjardins, R.P., et al.: Composite bone grafts and titanium implants in mandibular discontinity reconstruction. Int J Oral Maxillofac Implants 3: 261-267 1988.

9) Kahnberg, K.E., Nyström, E., et al.: Combined use of bone grafts and Brånemark fixtures in the treatment of severely resorbed maxillae. Int J Oral Maxillofac Implants 4: 297-304 1989.

10) Sailer, H.F.: A new method of inserting endosseous implants in totally atrophic 
maxillae. J Cranio Max Fac Surg 17: 2993051989.

11) Adell, R.A., Lekholm, U., et al.: Reconstruction of severely resorved edentulous using osseointegrated fixtures in immediate autogenous bone grafts. Int $\mathrm{J}$ Oral Maxillofac Implants 5: 233-246 1990.

12) Farmand, M: Long-term results after horseshoe sandwich osteotomy of the edentulous maxilla as a preprothetic procedure. J Cranio Max Fac Surg 20: 171-177 1992.

13) Nilsson, P., Albrektsson, T., et al.: The effect of hyperbaric oxygen treatment on bone regeneration: An experimental study using the bone harvest chamber in the rabbit. Int J Oral Maxillofac Implants 3: 43481988.

14) Sindet-Pederson, S. and Enemark, H.: Mandibular bone grafts for reconstruction of alveolar clefts. J Oral Maxillofac Surg 46: 533-537 1988.

15) Misch, C.M., Misch, C.E., et al.: Reconstruction of maxillary alveolar defects with mandibular symphysis graft for dental im- plant: A preliminary procedural report. Int J Oral Maxillofac Implants 7: 360-366 1992.

16) Brånemark, P-I: Osseointegration and its experimental background. J Prosthet Dent 50: 399-410 1983.

17) Lekholm, U., Adell, R., et al.: Marginal tissue reactions at osseointegrated titanium fixtures. II - A cross-sectional retrospective study. Int J Oral Maxillofac Surg 15: 53-61 1986.

18) Sennerby, L., Carlsson, G.F., et al.: Mandibular bone resorption in patients treated with tissue-intergrated prosthesis and in complete-denture wearers. Acta Odontol Scand 46: 135-140 1988.

19) Tolman, D.E., Desjardins, R.P., et al.: Surgical-prosthodontic reconstruction of oronasal defects utilizing at the tissue-integrated prosthesis. Int $\mathrm{J}$ Oral Maxillofac Implants 3: 31-40 1988.

20）上田実, 沢木佳弘, 他 : Osseointegrated implant (Brånemark System) を用いて咬合再建 を行った 5 例一咀嚼能力の変化を中心に一。 日 口外誌 36：704-711 1990. 